\title{
Game Theory Application on Funding Strategy PT. Bank Syari’ah Mandiri and PT. Bank BNI Syari'ah Facing the Competition of Islamic Banking Industry in Indonesia
}

\section{Tegar Wijanarko ${ }^{1}$ and Eko Fajar Cahyono ${ }^{2}$}

${ }^{1}$ Student of Department of Islamic Economics, Faculty of Economics and Business Universitas Airlangga Surabaya

${ }^{2}$ Lecturer of Department of Islamic Economics, Faculty of Economics and Business Universitas Airlangga Surabaya

\section{Abstract}

This study aims to show the application of game theory on the funding strategy of PT. Bank Syariah Mandiri and PT. Bank BNI Syariah in facing competition of syariah banking industry in Indonesia. The approach used is descriptive quantitative by using

Corresponding Author:

Tegar Wijanarko

tegarw96@gmail.com

Received: 10 February 2019

Accepted: 14 March 2019

Published: 28 March 2019

Publishing services provided by

Knowledge E

(c) Tegar Wijanarko and Eko

Fajar Cahyono. This article is

distributed under the terms of

the Creative Commons

Attribution License, which

permits unrestricted use and

redistribution provided that the

original author and source are

credited.

Selection and Peer-review under the responsibility of the ICIEBP Conference Committee.

\section{S OPEN ACCESS} payoff matrix analysis technique in game theory between PT. Bank Syariah Mandiri and PT. Bank BNI Syari'ah as research subject and funding strategy as object of research and DPK, hajj fund, number of customer as indicator of payoff. The results showed that the Nash Ekuilibrium and the Prisoner's Dilemma were not found in this game. Dominant strategy that get the highest payoff from each banks is a strategy to increase the promotion and marketing of haji cheap more aggressive to increase core deposit in anticipation of the decrease of funds due to the establishment of Hajj Financial Management Agency (BPKH) with 32,1 score for PT. Bank Syariah Mandiri and mass-funding strategy in partnership with BNI in the form of agency cooperation / Sharia Services Bank and synergize with micro outlet for marketing DPK with 25,4 score for PT. Bank BNI Syariah.

Keywords: Game Theory, Strategy, Bank Funding, Islamic Bank

\section{Introduction}

Indonesia is a country with the largest number of moeslim's in the world who contributing at least $10.6 \%$ from the total of moeslim in in the world make Indonesia become a potential development of Islamic banking sector and finance.

Islamic banking in Indonesia shows positive growth every year. Start on 1st May 1992 Muamalat Bank became the first Islamic Bank in Indonesia as a pioneer of the establishment of Islamic banks in Indonesia. Until 2017 Islamic banks statistics show there was 13 Islamic bank in Indonesia. The existence of the trend of emerging Islamic 
banks in Indonesia make customers of Islamic banks presented with many options to choose Islamic banks. This fact is make competition between Islamic banks are getting increased.

One another fact from increasing competition in the Islamic bank industry is the research conducted by Abdu (2017). In his research show that the competitive condition of Islamic banking in Indonesia leads to monopolistic competition.

TABLE 1: Sharia Banking Rating Based on Assets.

\begin{tabular}{lc} 
Islamic Bank & Assets (in trillions) \\
\hline PT. Bank Syari'ah Mandiri & 87,94 \\
PT. Bank BNI Syari'ah & 33,17 \\
Source: Annual Report of Bank Syari'ah Mandiri 2017 and Bank BNI Syari'ah 2017
\end{tabular}

Of the several Syariah banks in Indonesia, if rated, banks that have substantial assets on Islamic banking industry in Indonesia is PT. Bank Syari'ah Mandiri and PT. Bank BNI Syari'ah.

Nicholson in his book discussing about game theory. Game theory is one of the main tools used by economists to study the selection of strategyes taken by the company. In some journals game theory applications have been widely used in analyzing strategyes in companies or industries. The advantages of the application of this game theory is the researchers can find out how big the effectiveness of a strategy in dealing with opponent strategy by using payoff matrix. Payoff matrix is used to show the results of reward (payoff) of the strategyes of different games, the results of reward (payoff) can be expressed in a unit of measure the effectiveness of such money, the percentage of growth, market share or otherwise in accordance with the objectives or achievements of the strategy. ( Nicholson, 1991: 89)

Responding to the fact about dinamics competitive of the Islamic banking industry in Indonesia and the absence of research that implements game theory in the banking industry is reasons how importance this research made.

\section{Literature Review}

According to Sudarsono (2003: 15), Islamic bank is a business institution whose main business is to collect funds, channel funds, provide services in the financial traffic and money circulation operating in accordance with the principles of shariah.

Nurul Huda (2012: 293) in his book explains that Sharia Financial Institution is a business entity or institution whose main wealth in the form of financial assets (financial 
asset) and nonfinancial assets or assets based on the principles of shari'ah. In accordance with the laws concerning Syariah banking in Indonesia, it is said that Syari'ah financial institution is an institution or activity entity is to withdraw funds from society and channel it to society based on Shariah principle. The depository financial institution or the Islamic bank collects funds from the public in the form of savings, time deposits, and current accounts received from savers (surplus units). Surplus units may take the form of companies, governments, households or people who have excess income after deducting the need for their consumption.

Antonio (1999: 36) in his book wrote there are some fundamental differences between Islamic banks and conventional banks.

1. In terms of contract and legality. Akad that committed in Islamic bank has a concept not only worldly but also ukhrawi because the contract is run based on Islamic shari'ah.

2. From the organizational structure. Syari'ah banking can have the same organizational structure as the conventional bank, but the differentiating aspect of syariah bank must have syari'ah supervisory board (DPS) which serves to oversee the bank's operations and its products in order to stay in harmony with the syari' Ah.

3. Type of business and business financed. In syari'ah banks, business or business financed does not escape from shariah filter.

4. From the work environment and corporate culture. The concept of amanah and siddiq must base every employee to create professionalism based on Islamic values, and in terms of reward and punishment also use the principle of justice in accordance with the principles of shariah.

From the above explanation, it can be seen that the principles of shari'ah become the fundamental rules that shape and regulate the relationship of sharia banks either from the internal side (management of business arrangement) also from the external side (arrangement of relationship with the customer / society). In relation to bank relations with customers, there are five basic principles of sharia banking in conducting transactions, namely principle, profit sharing principle, lease principle, buying and selling principle, depository, and service principle (Satyo dan Izza, 2000).

Cashmere (2014: 58) said that the source of funds is the funds generated from the bank for the bank's efforts to raise funds. The sources of bank funds include:

1. Funds sourced from the bank itself 
The source of this bank's fund is a source of funds derived from the bank's private capital. Personal capital can come from capital payments from shareholders, bank reserves, or undistributed bank profits.

\section{Funds originating from other communities}

The source of bank funds from the public is the main source of funds in the bank's operational activities. This source of funds is also a measure of the success of a bank in the activity of raising funds from the community. These funds can be in the form of demand deposits, savings or deposits.

3. Funds originating from other institutions

This bank's source of funds is another additional source that banks get when the bank is in trouble. The source of this bank fund can be Liquidity Credit from Bank Indonesia, Interbank Calls (call money), Loans from foreign banks, or Money Market Securities (SBPU).

According to Nicholson (2007: 386) in his book one of the main tools used by economists to study the selection of strategyes taken by the company is the game theory. This game theory model tries to describe strategyc or complex situations in a very simple way. The game theory model summarizes the details of one problem to it's mathematical form. The main strength of this type of modeling is that it allows us to reach the core of a problem. Every situation where individuals have to make strategyc choices and the end result depends on the actions chosen by each person, can be viewed as a game. All games have three basic elements: players, strategyes and rewards.

Nicholson (2007: 386) says that players as a major and most important element in a game. Each player will be the decision maker to win the game. Each decision maker in a game is called a player. Players can be individuals, companies or entire countries. All pemian considered to have the ability to sort out among the many possible actions. An important assumption usually made in game theory (as in most economic studies) is that the identity of the players is irrelevant. There are no "good guys" or "bad guys" in a game, and the players are assumed to have no special abilities or special obstacles. Each player is assumed to choose the action that promises the most profitable results.

Nicholson (2007: 387) explained that a strategy is formed to deal with the strategy of other players. Each action that is open to a player is called by a strategy. A strategy may be a very simple action or a very complex action, depending on the type of game being discussed. However, each strategy is assumed to be a specific and defined action with good. Although some games offer players a number of different strategyes, some important results can be illustrated for situations where each player has only two 
strategyes available. Players may use a "combination" strategy by choosing to play their strategy randomly. In noncooperative games, players can not reach agreement with one another about what strategy they will play. Each player does not know exactly what the other players will do.

Then the latter is rewarded, in his book Nicholson (2007: 387) explains that rewards are the feedback or outcome of any strategy that has been executed by each player. The rewards are usually measured by the player's level of satisfaction, although often used in returns with monetary units (eg profit for a company). In general, it can be assumed that players can rank games from the most preferred to the less favored and will seek rewards with the highest attainable rank. Naturally, players will prefer rewards that offer more satisfaction than rewards that will only offer a lack of satisfaction to their company or business.

Salvatore (2005: 96) said that the Nash equilibrium is a situation when each player is in balance of each of his optimum strategyes, to face the strategy that has been done by other players. The Nash equilibrium is an equilibrium between two parties in which each parties or company will choose the best option for the company. Not every player has Nash equilibrium. Some of Nash equilibrium is not always owned and is not always desirable for players in a game.

Salvatore (2005: 95) says dominant strategy is the choice of strategy that gets the most optimum results for a player in the face of any reaction that is used by other players. The dominant strategy is the strategy that generates the highest rewards for the various strategyes used, but it is independent of the strategyes that other players use. Usually dominant strategy tends to lead to a strategy that has been tested for success in achieving rewards or optimal strategy results in a competition. Dominant strategy can also be said as a typical strategy of a company that is not owned by other companies or the successful implementation of such strategyes can only be achieved by companies that run this dominant strategy. The existence of this dominant strategy will generally make the company superior to other companies because the strategy applied is not affected by any strategy that will be done by other companies.

Nicholson (2007: 394) defines a prisoner dilemma as a game in which the maximum results gained by players or firms is generated at the expense of an option. The prisoner dilemma was first introduced by AW. Tucker in the 1940s. The concept of this game is more to explore decision-making strategyes taken by two parties that move and act in accordance with the interests of each parties and work together with each other will be more profitable than by moving on their own. Such conditions usually occur when a company in running the strategy together to get maximum results, but if it continues 
then the two companies will be threatened will not benefit more than that again. In order to gain greater profits than to survive only with fixed profits, the company will inevitably have to choose a bekoalisi for greater profit.

\subsection{Islamic business ethic}

Based on the basic principles of business ethics theologically, Islam teaches about moral and basic values or general principles whose application in business is adjusted to the times and considers the dimensions of space and time. The core values of Islamic business ethics are tauhid, khilafah, worship, tazkhiyah, and ihsan. From these core values can be raised to general principles including honesty, justice, responsibility, openness (transparency), togetherness, freedom, and accountability

\subsection{Previous research}

TABLE 2

\begin{tabular}{|c|c|}
\hline No. & Title \\
\hline 1. & $\begin{array}{l}\text { Game Theory Application in } \\
\text { humanitarian operation: a review }\end{array}$ \\
\hline 2. & $\begin{array}{l}\text { Prisoner's Dilema Game Dalam } \\
\text { Perdagangan Internasional: Teori } \\
\text { dan Bukti Empiris }\end{array}$ \\
\hline 3. & $\begin{array}{l}\text { Konflik Indonesia-Jepang dalam } \\
\text { pasar otomotif: Penerapan AHP dan } \\
\text { Game Theory }\end{array}$ \\
\hline 4. & $\begin{array}{l}\text { Analisis preferensi manajemen } \\
\text { terhadap strategi pengukuran } \\
\text { kinerja dengan mengintegrasikan } \\
\text { BSC dan Game Theory }\end{array}$ \\
\hline 5. & $\begin{array}{l}\text { Dominasi peran negara dalam era } \\
\text { kapitalisme global: aplikasi game } \\
\text { theory dalam studi kasus } \\
\text { perdagangan China dan Amerika } \\
\text { Serikat (1994-2010) }\end{array}$ \\
\hline 6. & $\begin{array}{l}\text { Penerapan teori permainan dalam } \\
\text { strategi pemasaran produk ban } \\
\text { sepeda motor }\end{array}$ \\
\hline 7. & $\begin{array}{l}\text { Analisis konflik majikan-buruh dalam } \\
\text { kerangka game theory: penerapan } \\
\text { AHP }\end{array}$ \\
\hline
\end{tabular}

\begin{tabular}{l} 
Author \\
Luke Muggi dan Jesicca L. \\
Jose Rizal Joesoef \\
Ahmad Jalil andJose Rizal \\
Mokh Afifudin Erwin Widodo I Ketut \\
Gunarta \\
Yonathan Susilo \\
Charles H.S. dan Elly R. \\
Jose Rizal Teguh Prasetyo Sulystiani \\
\hline
\end{tabular}




\section{Methodology}

The method used in this research is descriptive quantitative method. According to Arikunto (2006: 98) descriptive quantitative method is a research method that aims to create a description of a situation objectively using numbers, ranging from data collection, interpretation of the data and the appearance and results.

According Nursalam (2013: 57) descriptive quantitative research is used to view the description of the phenomenon and the description of activities carried out systematically and more emphasis on factual data.

\subsection{Identify variables}

The variable used in this research is from funding strategy of PT. Bank Syariah Mandiri and PT. Bank BNI Syari'ah in 2016 which is sourced from the annual report of PT. Bank Syari'ah Mandiri and PT Bank BNI Syari'ah in 2015. The strategy used by the two banks are as follows:

\subsubsection{Strategy of PT. Bank Syari’ah Mandiri}

Strategy 1: Approach of promotional activities that are aligned with the intended target market through Customer Centric approach to increase DPK by 2016.

Strategy 2: Increase the promotion and marketing of more aggressive low cost to increase core deposit in anticipation of the decrease of fund due to establishment of Haj Financial Management Agency (BPKH).

Strategy 3: Simplification of products and processes to improve customer satisfaction. This strategy as a follow-up evaluation of customer response and preferences that want more experience (in terms of products, services, and attendance) of the Sharia Bank.

\subsubsection{Strategy of PT. Bank BNI Syari'ah}

Strategy 1: Mass-funding strategy in partnership with BNI Parent in the form of agency collaboration / Sharia Bank Service (LSB) and synergize with micro outlet for marketing of DPK. 
Strategy 2: Establish Hajj \& Umrah Desk to develop great business potential and opportunity for Hajj and Umrah business, and in order to implement one stop Haj and Umrah.

Strategy 3: Cooperate with Universities and Institutions and develop product and service features to institutional customers.

\subsection{Operational definition}

\subsubsection{Players}

1. PT. Bank Syari’ah Mandiri

2. PT. Bank BNI Syari'ah

\subsubsection{Payoff strategy indicators}

The indexing carried out in this study refers to the targets or achievements of each funding strategy in the annual reports of PT. Bank Syari'ah Mandiri and PT. BNISyari'ah, while the use of growth percentage as indicator measure refers to the thesis of Willyanto K. "ANALYSIS OF FINANCIAL RATIO AS INDICATORS IN PREDICTING THE BANKING POTENTIAL BANKING IN DI INDONESIA" but modified by the researchers in accordance with the object of research is the funding strategy of Islamic bank.

TABLE 3: Funding Strategy Indicator of PT. Bank Syari'ah Mandiri dan PT. Bank BNI Syariah.

\begin{tabular}{l|l}
\multicolumn{2}{c}{ PT. Bank Syari'ah Mandiri } \\
Strategy & Payoff Indicator \\
Strategy 1 & $\begin{array}{l}\text { Precentage of DPK growth PT. } \\
\text { Bank Syari'ah Mandiri in } \\
\text { 2015-2016 }\end{array}$ \\
Strategy 2 & $\begin{array}{l}\text { Precentage of hajj and umrah } \\
\text { fund growth PT. Bank Syariah } \\
\text { Mandiri in 2015-2016 }\end{array}$ \\
Strategy 3 & $\begin{array}{l}\text { Precentage number of } \\
\text { customer growth PT. Bank } \\
\text { Syari'ah Mandiri in 2015-2016 }\end{array}$ \\
\hline
\end{tabular}

\begin{tabular}{ll}
\hline & \multicolumn{1}{c}{ PT. Bank BNI Syari'ah } \\
Strategy & Payoff Indicator \\
Strategy 1 & $\begin{array}{l}\text { Precentage of DPK growth PT. } \\
\text { Bank BNI Syari'ah in } \\
\text { 2015-2016 }\end{array}$ \\
\hline Strategy 2 & $\begin{array}{l}\text { Precentage of hajj and umrah } \\
\text { fund growth PT. Bank BNI } \\
\text { Syari'ah in 2015-2016 }\end{array}$ \\
\hline Strategy 3 & $\begin{array}{l}\text { Precentage number of } \\
\text { customer growth PT. Bank } \\
\text { BNI Syari'ah in 2015-2016 }\end{array}$ \\
\hline
\end{tabular}

\subsection{Types and data sources}

The type of data used in this study is primary data and secondary data. 


\subsubsection{Primary data}

Primary data is data obtained directly from the object to be studied. In this study the primary data obtained from the observation directly on the object of research with the participation of researchers to customers in PT. Bank Syari'ah Mandiri Surabaya branch and PT. Bank BNI Syariah Surabaya branch so that researchers can directly know the general description of the funding strategy of PT. Bank Syariah Mandiri and PT Bank BNI Syari'ah.

\subsubsection{Secondary data}

In this case the data source used in this study is an official document in the form of a publication of annual reports and sustainbility report of PT. Bank Syariah Mandiri and PT BNI Syariah. According to Moleong (2011: 219) the official document is divided into internal documents and extracurricular documents. Internal documents can be memos, announcements, instructions, rules of a particular community institution used within its own circle. Documents referred to in this study namely Brochures, Ads, sustainbility report and annual reports of PT. Bank Syari'ah Mandiri and PT. Bank BNI Syariah.

\subsection{Data collection procedures}

In this research the data collection procedure is done as follows:

\subsubsection{Library research}

In this research data collection methods by library research that collects data in the form of strategy of PT. Bank Syari'ah Mandiri and PT. Bank BNI Syari'ah from annual report of PT. Bank Syariah Mandiri and PT. Bank BNI Syari'ah in 2015 and 2016, research or journals that discuss about the application of game theory and the literature that discusses about game theory.

\subsubsection{Observation}

In this research, researcher directly to become a customer in PT. Bank Syari'ah Mandiri and PT. Bank BNI Syariah so expected to get a reprsentation directly about the implementation of strategy PT. Bank Syari'ah Mandiri and PT. Bank BNI Syari'ah. 


\subsection{Analysis technique}

The analysis technique used in this research is the analysis with game theory approach that is by using payoff matrix. Payoff matrix is a matrix that shows the payoffs of different game strategyes, these results are expressed in terms of effectiveness measures such as money, percentage, market share, utilities, etc.

Step analysis conducted in this research is to take a strategy sample in the form of strategy only focus on funding strategy of 2016 from PT. Bank Syariah Mandiri and PT. Bank BNI Syariah in the annual report of PT. Bank Syariah Mandiri and PT. Bank BNI Syariah in 2015. After that determine the indicator of the results of each strategy. Scoring of each indicator is based on an increase growth percentage of each indicator. Apply the scores obtained to the payoff matrix and analyze the results of the payoff matrix, drawing conclusions from the analysis of the research results.

\section{Result and Discussion}

\subsection{Result}

\subsubsection{Payoff matrix}

TABLE 4: Payoff Funding Strategy of BSM and BNIS.

\begin{tabular}{l} 
BSM BNIS \\
Strategy 1 \\
\hline Strategy 2 \\
\hline Strategy 3 \\
\hline
\end{tabular}

\begin{tabular}{|c|}
\hline Strategy 1 \\
\hline 12,6 \\
\hline 25,4 \\
\hline 12,6 \\
\hline 16,4 \\
\hline 12,6 \\
\hline 5,4 \\
\hline
\end{tabular}

\begin{tabular}{|c|}
\hline Strategy 2 \\
\hline 32,1 \\
\hline 25,4 \\
32,1 \\
16,4 \\
\hline 32,1 \\
\hline 5,4
\end{tabular}

\begin{tabular}{|c|}
\hline Strategy 3 \\
\hline 2,3 \\
\hline 25,4 \\
\hline 2,3 \\
\hline 16,4 \\
\hline 2,3 \\
\hline 5,4 \\
\hline
\end{tabular}

\subsubsection{Description of research results}

The result of the above research is we can see payoff obtained by PT. Bank Syariah Mandiri and PT. Bank BNI Syari'ah in 2016 from each funding strategy between PT. Bank Syari'ah Mandiri and PT. Bank BNI Syari'ah in 2015. It can be seen also how the response between funding strategy with one another between PT. Bank Syari'ah Mandiri and PT. Bank BNI Syari'ah in 2016. 
Strategy 1 PT. Bank Syari'ah Mandiri lost 12.8 points against strategy 1 and lost 3.8 points against strategy 2 from PT. Bank BNI Syariah but won 7.2 points against strategy 3 PT. BNI Syari'ah. While strategy 2 PT. Bank Syari'ah Mandiri won from all the strategyes of PT. BNI Syari'ah with a 6.7 points win against strategy 1, winning 15.7 points against strategy 2 and winning 26.7 points against strategy 3 from PT. Bank BNI Syariah. And strategy 3 from PT. Bank Syari'ah Mandiri lost 23.1 points against strategy 1, 14.1 points against strategy 2, and 3.1 points against strategy 3 from PT. Bank BNI Syari'ah.

Strategy 1 PT. Bank BNI Syari'ah won 12.8 points against strategy 1 and won 23.1 points against strategy 3 from PT. Bank Syari'ah Mandiri but lost 6.7 points against strategy 2 from PT. Bank Syari'ah Mandiri. Strategy 2 PT. Bank BNI Syari'ah won 3.8 points against strategy 1 and won 14.1 points against strategy 3 from PT. Bank Syariah independent but lost 15.7 against strategy 2 from PT. Bank Syari'ah Mandiri. And strategy 3 PT. BNI Syari'ah won 3.1 points against strategy 3 from PT. Bank Syariah Mandiri but lost 7.2 points against strategy 1 and lost 26.7 points against strategy 2 from PT. Bank Syari'ah Mandiri.

From the third parties fund collection (DPK) of PT. Bank BNI Syari'ah winning by getting a score of 25.4 on the percentage of DPK growth from the year 2015-2016 amounted to $25.4 \%$ while PT. Bank Syari'ah Mandiri get 12.6 score on the percentage growth of deposits from $2015-2016$ of $12.6 \%$.

From the collection side of Hajj funds PT. Bank Mandiri Syari'ah excelled by getting a score of 32.1 on the percentage growth of Hajj funds from 2015-2016 amounted to 32.1\% while PT. Bank BNI Syari'ah received a score of 16.4 on the percentage growth of Hajj funds from $2015-2016$ of $16.4 \%$.

In terms of number of customers PT. Bank BNI Syari'ah excel by getting a score of 5.4 percentage of the growth of the number of customers from 2015-2016 amounted to $5.4 \%$ while PT. Bank Syariah Mandiri mendapaktan score of 2.3 percentage of the growth of the number of customers from $2015-2016$ of $2.3 \%$

The results of payoff obtained by PT. Bank Syari'ah Mandiri and PT. Bank BNI Syari'ah in 2016 from each funding strategy between PT. Bank Syari'ah Mandiri and PT. Bank BNI Syari'ah in 2016 researchers try to analyze whether there is a condition of balance Nash and dilemma prisoners that occur in the competition between PT. Bank Syariah Mandiri and PT. Bank Syari'ah Bank and analyze what strategyes become the dominant strategy of each bank with the results of the analysis serve on this table: 


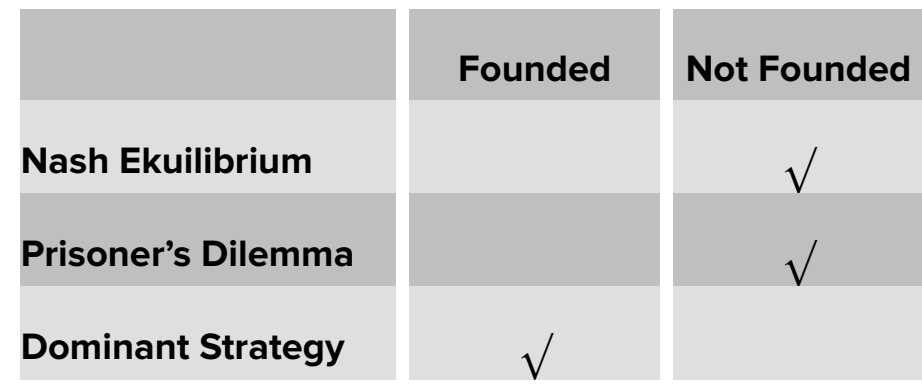

\subsubsection{Nash ekuilibrium condition}

Although there is a balance between strategy 3 PT.Bank Syari'ah Mandiri and PT. Bank BNI Syari'ah with the smallest payoff between payoff strategy 3 PT. Bank Syari'ah Mandiri of 2.3 and payoff strategy 3 PT. Bank BNI Syariah of 5.4 with only 3.1 points difference. However, in the game between PT. Bank Syari'ah Mandiri and PT. BNI Syari'ah condition of balance Nash not found because found equal payoff result from strategy 3 PT. Bank Syari'ah Mandiri and PT. Bank BNI Syari'ah where strategy 3 from PT. Bank Syari'ah is independent and strategy 3 PT. Bank BNI Syariah is not an optimum strategy of PT. Bank Syari'ah Mandiri and PT. Bank BNI Syari'ah. On the PT. Bank Syariah Mandiri optimum strategy is on strategy 2 that is to promote promotion and marketing hajj cheap more aggressive to increase core deposit in anticipation of the decline of funds due to the establishment of Haj Financial Management Agency (BPKH) oriented to the achievement of growth Hajj Fund while the optimum strategy on the PT. BNI Syari'ah is on strategy 1 is mass funding in cooperation with BNI Parent in the form of collaboration agency / Islamic Banking Service (LSB) and synergize with micro outlet for marketing DPK. This is in accordance with the Nash balance theory which can be said that Nash balance occurs when both firms get balanced results on their respective optimum strategyes.

\subsubsection{Prisoner's dilemma condition}

In the game between PT. Bank Syari'ah Mandiri and PT. BNI Syari'ah not found condition of dilemma of prisoner. This is because in the formulation of the strategy of 2015 the two banks are not founded a interfered with each other strategy. In addition, the market conditions of competition between the two banks that lead to the market of monopolistic competition makes the absence of market control so that no pressure which causes the company to experience the conditions of the prisoner's dilemma. 


\subsubsection{Dominant strategy}

The dominant strategy of PT. Bank Syari'ah Mandiri with the highest payoff is strategy 2 that is to increase promotion and marketing hajj cheap more aggressive to increase core deposit in anticipation of decrease of fund due to establishment of Haj Financial Management Agency (BPKH) with get highest payoff equal to 32,1 growth of hajj fund by $32.1 \%$ from 2015 .

The dominant strategy of PT. Bank BNI Syariah with the highest payoff is strategy 1 that is mass funding strategy by way of cooperation with BNI Parent in the form of cooperation of agency / Service Syariah Bank (LSB) and synergize with micro outlet for marketing DPK. Getting the highest payoff of 25.4 on deposits growth of $25.4 \%$ from 2015.

And views from business ethics in Islam prespective the competition that occurred between PT. Bank Syari'ah Mandiri and PT. BNI Syari'ah Bank is in accordance with the rules that exist in the Islamic business is honesty this can be seen during the work in the world of syariah banking these two banks have a good reputation and never commit fraudulent actions that harm customers. Justice is reflected by always serving all segments of consumers well without discriminating the background of its consumers, this responsibility is reflected through social activities conducted in corporate social responsibility that annually done by both banks. Then in terms of transparency (transparency), togetherness, freedom is reflected in the competition made by both banks can be said that these two banks compete in a healthy way does not cover the information of each other and also do not do interverensi that can knock the opposing side either from the side strategyes used, advertisements used to promote their products and practices. and accountability is reflected in regular financial reporting and bank performance annually.

\subsection{Conclusion}

The conclusion of game theory application research on PT. Bank Syariah Mandiri and PT. Bank BNI Syariah strategy is able to know that the condition of Nashekuilibrium and prisoner dilemma are not found in the game. While the dominant strategy that generates the highest payoff from both banks is a strategy to increase the promotion and marketing of hajj cheap more aggressive to increase the core deposit in anticipation of the decrease of funds due to the establishment of Haj Financial Management Agency (BPKH) for PT. Bank Mandiri Syari'ah and mass funding strategy in collaboration with BNI 
Induk in the form of agency cooperation / Islamic Sharia Services (LSB) and synergize with micro outlet for marketing DPK for PT. Bank BNI Syari'ah.

\subsection{Suggestion}

1. From the research result between PT. Bank Syari'ah Mandiri and PT. Bank BNI Syari'ah researchers suggest for PT. Bank Syari'ah Mandiri gives more attention to the strategy to increase the number of customers because of the three funding strategyes undertaken by PT. Bank Syariah Mandiri is known that the strategy to increase the number of customers get relatively smaller growth compared to other strategyes.

2. From the research results between PT. Bank Syariah Mandiri and PT. Bank BNI Syariah researchers suggest for PT. Bank BNI Syari'ah pay more attention to the strategy to increase the number of customers because of the three funding strategyes undertaken by PT. Bank BNI Syari'ah known that the strategy to increase the number of customers get relatively smaller growth compared with other strategyes.

3. Because the research is still limited to analyze the funding strategy, for the next researcher is expected to develop game theory application model to be used in other strategy besides funding strategy so that the whole strategy can be analyzed through game theory model. Because in this study is still limited to analyze the funding strategy

4. For the society is expected to be able to assess more objectively in choosing which syari'ah bank products are more appropriate syari'ah, superior and more bring benefits and blessings for customers of Islamic banking in Indonesia.

\section{References}

[1] Al-Qur'an

[2] Arikunto, Suharsimi. 2002. Prosedur Penelitian Suatu Pendekatan Praktek.Jakarta: Rineka Cipta

[3] Aziz, Abdul. 2013. ETIKA BISNIS PRESPEKTIF ISLAM Implementasi Etika Is/ami untuk Dunia Usaha. Bandung: CV. ALFABETA

[4] bi.go.id

[5] Cupian dan Abdu,Muhammad. 2017. Competitive Condition and Market Power of Islamic Banks in Indonesia. Emerald Insight 
[6] David, Fred R. 2009. Strategyc Management Manajemen Strategys Konsep. Jakarta. Salemba Empat

[7] Hendratmi, Achsania. Model Manajemen Strategy Syari'ah: Suatu Pengantar.

[8] Joesoef,Jose Rizal. 2001. Prisoner's Dilema Game Dalam Perdagangan Internasional: Teori dan Bukti Empiris. Malang. Universitas Gajayana Malang

[9] Karim, Adiwarman. 2007. Ekonomi Mikro Islami. Jakarta: PT. Raja Grafindo Persada

[10] Kasmir. 2014. Bank dan Lembaga Keuangan Lainnya Edisi Revisi. Jakarta. PT. Raja Grafindo Persada

[11] Nazir. 2003. Metode Penelitian. Jakarta: PT. Ghalia Indonesia

[12] Nicholson, Walter. 1991. Mikroekonomi Intermediate dan Penerapannya edisi ketiga Jilid 1.Jakarta: ERLANGGA

[13] PT. Bank BNI Syari'ah. 2015. Annual Report 2015. Jakarta: PT. Bank BNI Syariah

[14] _ 2015. Annual Report 2016. Jakarta: PT. Bank BNI Syari'ah

[15] _ 2015. Coorporate Sustainbility Report 2016. Jakarta: PT. Bank BNI Syari'ah

[16] _ 2016. Coorporate Sustainbility Report 2016. Jakarta: PT. Bank BNI Syari'ah

[17] PT. Bank Syariah Mandiri. 2015. Annual Report 2015. Jakarta: PT. Bank Syariah Mandiri

[18] _ 2016. Annual Report 2016. Jakarta: PT. Bank Syari'ah Mandiri

[19] _. 2015. Coorporate Sustainbility Report 2015. Jakarta: PT.BankSyariah Mandiri

[20] _ 2016. Coorporate Sustainbility Report 2016. Jakarta: PT.Bank Syari'ah Mandiri

[21] Salvatore, Dominick. 2007. MIKROEKONOMI Edisi Keempat. Jakarta: PT. Gelora Aksara

[22] Soeharno. 2007. Teori Mikroekonomi. Yogyakarta: CV. ANDI OFFSET Statistik Perbankan Syari'ah OJK Oktober 2017

[23] Sukirno, Sadono. Pengantar Teori Mikroekonomi. Jakarta: Rajawali Pers 